\title{
Effect of Thermosensitization with Parthenolide in Thermotherapy of Early Prostate Cancer Combined with Androgen Deprivation; with an Emphasis on Histopathologic Findings
}

\author{
KEN KOSHIBA $^{1 *}$, SACHIKO HAYASHI ${ }^{2}$, MASAHIRO AIHARA ${ }^{3}$, \\ TAKEFUMI SATO ${ }^{4}$, YUTAKA JUJO ${ }^{1}$, RYUTA SUZUKI ${ }^{1}$, \\ HIDEYUKI MIZOGUCHI ${ }^{1}$, MASANORI HATASHITA ${ }^{5}$, \\ HIROTAKA NAKAJO ${ }^{6}$, SATORU SHIMURA ${ }^{7}$
}

\footnotetext{
${ }^{1}$ Center for Urology and Nephrology, Saitama ken-oh Hospital, 1726 Okegawa, Saitama 363-0008, Japan

${ }^{2}$ Department of Experimental Radiology and Health Physics, University of Fukui, Eiheiji-cho, Fukui 910-1193,

Japan

${ }^{3}$ Kurihama Urology Clinic, 1-3-18 Kurihama, Yokosuka 239-0831, Japan

${ }^{4}$ Department of Urology, Kitasato University School of Medicine, Sagamihara 252-0374, Japan

${ }^{5}$ Research and Development Department, The Wakasa-wan Energy Research Center, Tsuruga, Fukui 914-0192, Japan

${ }^{6}$ Department of Urology, Nagatsuda Kosei General Hospital, 4-23-1 Nagatsuda, Midori-ku, Yokohama 226-0027, Japan

${ }^{7}$ Department of Urology, Yokohama General Hospital, 2210 Kurogane-cho, Midori-ku, Yokohama 225-0025, Japan
}

Abstract: Parthenolide (PTL), a nuclear factor $\varkappa \mathrm{B}(\mathrm{NF}-\varkappa \mathrm{B})$ inhibitor, has been known to have a significant thermo-enhancement effect. The purpose of this study is to report our clinical experiences of using PTL in perioperative period of transurethral microwave thermotherapy (TUMT) for the treatment of early prostate cancer and to compare the results with those of the patients who were treated in the similar manner without PTL administration. All the patients who underwent TUMT for early prostate cancer were pretreated with androgen deprivation therapy (ADT) at least for 3 months to reduce volume of the prostate to render the TUMT more effective. PTL, daily oral dose of $0.5 \mathrm{mg}$, was administered during the perioperative period of TUMT.

Forty-five patients with early prostate cancer, clinical stage T1c $\sim \mathrm{T} 2 \mathrm{cN} 0 \mathrm{M} 0$ were included in this study. Significant reduction in volume of the prostate (mean 34.6\%) was noted after ADT for 3 months. Transurethral resection of the prostate in radical fashion was then performed at least 3 months after TUMT to wait for maturation of histopathologic changes of the prostate glands.

Thorough histopathologic study of all the transurethral resection of the prostate (TURP) chips revealed no cancer cell in 41 of 45 patients. Among 4 patients who were found to have remnant cancer cells in TURP chips, 1 was with non-viable cancer cells. Whereas, 3 were with probably viable cancer

Received 3 April, 2013, Accepted 14 May, 2013. *Corresponding author; Tel, +81-3-3821-0502; Fax, +81-3-3821-1194;

e-mail, ken604k@ma.kitanet.ne.jp

doi : $10.3191 /$ thermalmed.29.47

(C) 2013 Japanese Society for Thermal Medicine 
cells, but apparently degraded in malignancy. These results were apparently superior to those of the 75 patients who were treated in similar manner before administration of PTL. Analyses were performed using Student's $t$-test, chi-square test and Fisher's exact test and ANOVA.

Key Words: parthenolide, thermosensitization, prostate cancer, androgen deprivation, TUMT

\section{Introduction}

Parthenolide (PTL), a sesquiterpen isolated from feverfew (Tanacetum parthenium), a medical herb, has been known to have antitumor activity ${ }^{1-3)}$. Besides, PTL is used in the west to treat such conditions as migraine and inflamation ${ }^{4,5}$. However, there was no known study of its effect in combination with hyperthermia until 2008, when Hayashi et $a l^{6}$ ) reported thermo-enhancement effect of PTL towards human lung cancer A549 cells. Furthermore Hayashi et al ${ }^{7)}$ reported its significant thermo-enhancement effect towards human prostate cancer androgen-independent cell lines PC3 and DU 145 in 2011.

Transurethral microwave thermotherapy (TUMT) was introduced as a minimally invasive clinical management for the treatment of benign prostatic hyperplasia (BPH) in 1990s. Although TUMT was originally introduced for the treatment of prostatic hyperplasia, its significant effectiveness on the treatment of early stage prostate cancer after reduction of volume of the prostate by androgen deprivation had recently been reproted ${ }^{8)}$.

In this study, clinical effect of PTL was evaluated by thorough histopathologic study of all the transurethral resection of the prostate (TURP) chips which were taken 3 months after TUMT on 45 patients. The findings were compared with those of 75 patients who were treated before the use of thermosensitization with PTL.

\section{Materials and methods \\ Patients}

Between October 2008 and April 2011, 45 patients with biopsy proven adenocarcinoma of the prostate, clinical stage $\mathrm{T} 1 \mathrm{c} \sim \mathrm{T} 2 \mathrm{c}$ NOM0, were enrolled in this study. The mean age of the patients was 71.8 (range 53 83) years. The mean serum prostate antigen (PSA) was 9.2 (range $4.0 \sim 34.1$ ) ng/ $\mathrm{ml}$. The mean prostatic volume (total volume including fibrous capsule of the prostate) at initial transrectal ultrasound (TRUS) measurement was $30.1 \mathrm{ml}$ (range 15.6 59.4). Gleason scores ${ }^{9}$ at initial TRUS biopsy were 6 or less in 17, $7(3+4)$ in 13, $7(4+3)$ in 7,8 in 3,9 in 4 and 10 in 1 patient. Clinical stages were T1c in 25, T2a in 9, T2b in 7 and T2c in 4 patients according to the 1992 TNM Staging System (Table I).

Table I. Baseline characteristics of 45 patients with parthenolide.

\begin{tabular}{cc}
\hline Characteristics & \\
Age (mean \pm SD) (years) & $71.8 \pm 5.6$ \\
PSA (mean \pm SD) $(\mathrm{ng} / \mathrm{ml})$ & $9.2 \pm 7.8$ \\
PSA level number $(\%)$ & \\
$4-10(\mathrm{ng} / \mathrm{ml})$ & $33(73.3)$ \\
$>10-20(\mathrm{ng} / \mathrm{ml})$ & $8(17.7)$ \\
$>20(\mathrm{ng} / \mathrm{ml})$ & $4(8.9)$ \\
Prostate volume (mean $\pm \mathrm{SD})$ & $30.1 \pm 9.9$ \\
$<20(\mathrm{ml})$ & $8(17.8)$ \\
$20.1-30(\mathrm{ml})$ & $15(33.3)$ \\
$30.1-40(\mathrm{ml})$ & $16(35.6)$ \\
$40.1-50(\mathrm{ml})$ & $4(8.9)$ \\
$>50(\mathrm{ml})$ & $2(4.4)$ \\
Clinical stage number $(\%)$ & \\
T1c & $25(55.5)$ \\
T2a & $9(20.0)$ \\
T2b & $7(15.6)$ \\
T2c c & $4(8.9)$ \\
$<6$ & \\
7 & $17(37.8)$ \\
8 & $20(44.4)$ \\
9 & $3(6.7)$ \\
10 & $4(8.9)$ \\
Gleason & $1(2.2)$ \\
\hline
\end{tabular}

PSA, Prostate specific antigen; Prostate volume, Total gland volume including fibrous capsule of the prostate measured by ultrasonography. 
A thorough discussion was held with each patient regarding this illness, the plan of this treatment, potential choice of other treatment modalities regarding this illness and written informed consent was obtained.

The histopathologic findings of their TURP chips which were obtained at least 3 months after TUMT with use of UroWave ${ }^{\mathrm{TM}}$ (Dornier MedTech Systems GmbH, Munich, Germany) were compared by thorough histopathologic examination with those of 75 patients $\left.^{8}\right)$ who were treated in a similar procedure before the administration of PTL.

\section{Androgen deprivation therapy}

The therapy started with oral administration of non-steroidal anti-androgen (bicalutamide $80 \mathrm{mg}$ / day) and was followed by subcutaneous administration of lutenizing hormone-releasing hormone (LH-RH) agonist (leuprorelin acetate $3.75 \mathrm{mg} / 4$ weeks in 31 patients and goserelin acetate $10.8 \mathrm{mg} / 12$ weeks in 14 patients) 2 weeks after starting oral administration of non-steroidal anti-androgen. High-energy TUMT was performed at least 12 weeks (mean 14.6) after initiation of LH-RH agonist therapy to wait for satisfactory reduction in prostate volume to render the thermotherapy more effective. The counting of length of androgen deprivation therapy (ADT) was started at the first LH-RH agonist administration and terminated at $6^{\text {th }}$ months $(4$ weeks $\times 6)$ after TURP in radical fashion. Total length of ADT was $15.7 \pm 2.5$ (mean $\pm \mathrm{SD}$ ) months.

\section{Thermosensitization by parthenolide}

PTL is a nuclear factor- $\varkappa \mathrm{B}(\mathrm{NF}-\varkappa \mathrm{B})$ inhibitor. It was investigated in the human prostate cancer androgen-independent cell lines PC3 and DU145 and its significant thermo-enhancement effect was confirmed by Hayashi et $a l^{7}$. We have utilized Tanacet $125^{\circledR}$ (Ashbury Biologicals, Toronto, Canada) as a remedy for this purpose. It is a standardized feverfew (Tanacetum parthenium) leaf product, which is a recognized traditional herbal remedy mainly for prevention of migraine as well as anti-tumor activity. According to Curry III $e t a{ }^{10)}$, feverfew, with up to $4 \mathrm{mg}$ of PTL, given daily as an oral tablet is well tolerated without dose-limiting toxicity.

In this study, Tanacet $125^{\circledR}$, which contains a minimum of $0.2 \%$ PTL, was used as a thermosensitizing remedy. We have administered 2 oral tablets daily (PTL $0.5 \mathrm{mg} / \mathrm{day}$ ). For the initial 30 patients, 2 tablet daily for 30 days were given orally to examine any physiological and biochemical changes due to PTL administration and it was followed by 15 days of oral administration during and after TUMT with UroWave ${ }^{\mathrm{TM}}$. Since we have noticed no detectable side effect of PTL on these 30 patients, pretreatment PTL administration has reduced to 15 days and followed by 30 days during and post-treatment period after TUMT. The total dose of PTL administration was $22.5 \mathrm{mg}$ in perioperative period of TUMT.

\section{Transurethral microwave thermotherapy}

The UroWave ${ }^{\mathrm{TM}}$ was used for TUMT. It is a high-energy TUMT device designed for treatment of $\mathrm{BPH}^{11,12)}$. It applies $915 \mathrm{MHz}$ microwave energy to the prostate via a helical coil antenna enclosed in a transurethral delivery system, which also contains a water-cooling circuit system to provide $360^{\circ}$ 
uninterrupted circumferential cooling. This prevents urethral mucosa from heat injury. The diameter of the urethral applicator is approximately $18 \mathrm{~F}$ when inflated with cooling water. Urethral applicator UA20 is a helical coil antenna $17.5 \mathrm{~mm}$ in length and UA30 is of $24.5 \mathrm{~mm}$ in length. An appropriate length of antenna was chosen according to the length of prostatic urethra of each patient. The system features a rectal probe, with a series of 3 thermal couples mounted on the anterior midline that continuously monitor the temperature at the rectal mucosa closest to the posterior aspect of the prostate. It serves as a key safety feature to prevent excessive heating of the rectal wall. For the present study, the safety threshold was set at $43.5^{\circ} \mathrm{C}$ in the urethral mucosa and at $43^{\circ} \mathrm{C}$ in the rectum. With these settings, peak intraprostatic temperature reaches as high as $65^{\circ} \mathrm{C}$. Mean temperature reaches a maximum of $55^{\circ} \mathrm{C}$ at a radial distance of approximately $4 \mathrm{~mm}$ from the urethral mucosa and remained $45^{\circ} \mathrm{C}$ or higher up to a distance of $16 \mathrm{~mm}$. The fibrous capsule serves as a barrier to pass microwave so as to prevent excessive heating of the rectal wall and external urethral sphincter, and it also helps to accumulate higher temperature to kill cancer cells inside the fibrous capsule of the prostate. This system is capable of delivering up to 90 watts of power to the targeted tissue. The median power we used in this series was 74 watts (range $35 \sim 90$ ). The patients were subjected to a 60 min treatment in an outpatient setting under local anesthesia. A $14 \mathrm{~F}$ indwelling urethral catheter was kept in place for 3 days after the treatment. Majority of the patients complained of no difficulty in urination after removal of the catheter. In 2 exceptional patients, however, longer indwelling catheter was needed, 2 and 3 weeks respectively.

\section{Regional hyperthermia}

Three days after TUMT and after removal of indwelling urethral catheter, all the patients underwent one session of regional hyperthermia using a radiofrequency capacitive heating system operated at $8 \mathrm{MHz}$ (Thermotron-RF8, Yamamoto Vinita, Osaka, Japan) ${ }^{13,14)}$ focused on lower pelvic cavity including the prostate at around center of it. Intrarectal temperature was measured using a 4-on the point microthermocouple sensor via a rectal tube at the level of the prostate so as to measure the treatment temperature and to record in a real time manner. The output power was set at $800 \sim 1,200$ watts, based on the patient's tolerance. The heating duration was equally $45 \mathrm{~min}$. In all patients, both the upper and lower electrodes were $30 \mathrm{~cm}$ in diameter and placed on opposite sides of lower pelvic region. The treatment posture was prone position in majority of the patients. Patients with subcutaneous adipose tissue thickness greater than $2.5 \mathrm{~cm}$ frequently complain of irritating sensation in the skin at the heating site, which cause a decrease in the effectiveness of the RF-capacitive heating device. However, at least one of the 4 intrarectal temperature measurement was reached $41.5^{\circ} \mathrm{C}$ or higher during the treatment. The upper limit of the temperature was set at $43.5^{\circ} \mathrm{C}$.

The purpose of this regional hyperthermia is to expect higher treatment effect by heating fibrous capsule of the prostate and periprostatic region as well. Since preceding TUMT is able to heat whole intraprostatic adenomatous tissue up to $45^{\circ} \mathrm{C}$ or higher, but microwave poorly penetrates fibrous capsule of the prostate.

\section{Transurethral resection of the prostate}

TURP was performed in radical fashion at least 3 months after thermotherapy. This is to remove 
glandular tissue of the prostate, as much as possible, until reaching to the fibrous capsule. As our policy, the verumontanum was kept intact, since prostate cancer rarely occurs in this area and also it is an important landmark to identify location of the external urethral sphincter. This procedure is not only to remove remnant cancer tissue, but also to confirm the treatment effect of thermotherapy under ADT and PTL administration. Interval of 3 month is to wait for maturation of tissue degeneration due to thermotherapy combined with ADT and PTL. Significant reduction in volume of the prostate and tissue degeneration due to ADT followed by thermotherapy made TURP easy and safe under clear vision with less blood loss than ordinary TURP for benign prostatic hyperplasia. All TURP chips were subjected to thorough histopathologic study divided into 5 parts; median, anterior, right lateral, left lateral and apex.

\section{Statistical analysis}

Data on age, serum PSA, Gleason score, histology and TRUS volume were analyzed with Student's $t$-test, chi-square test, Fisher's exact test and ANOVA. Differences were considered significant with the $P$-value $<0.05$. The OR and 95\% CI were calculated for histology.

\section{Results}

\section{Reduction in volume of the prostate}

The mean volume of the prostate including fibrous capsule of the prostate measured by TRUS was $30.1 \mathrm{ml}$ at initial diagnosis. Significant reduction in prostatic volume (mean 34.6\%) was noted after ADT for 3 months. At TUMT, the mean volume of the prostate was $19.5 \mathrm{ml}$. It was thought to be small enough to be thoroughly heated by high-energy microwave down to the peripheral prostate. In another 3 months after TUMT and continued ADT, reduction in volume of the prostate was $51.7 \%$ of the original volume at diagnosis. The mean weight of TURP chips was 6.4 grams. These figures are grossly compatible with those of the control group ${ }^{8)}$ before PTL administration (Table II).

Table II. Reduction in volume of the prostate measured by ultrasonography (45 patients with use of parthenolide).

\begin{tabular}{lllcl}
\hline & $\begin{array}{c}\text { Before treatment } \\
\text { TRUS }(\mathrm{ml})\end{array}$ & $\begin{array}{c}\text { 12 weeks after } \\
\text { ADT TRUS }(\mathrm{ml})\end{array}$ & $\begin{array}{c}\text { 12 weeks after } \\
\text { TUMT TRUS }(\mathrm{ml})\end{array}$ & $\begin{array}{c}\text { TURP Wt } \\
(\mathrm{g})\end{array}$ \\
\hline $\mathrm{n}=$ & 45 & 43 & 45 & 45 \\
Mean $\pm \mathrm{SD}$ & $30.1 \pm 9.9$ & $19.5 \pm 7.3$ & $14.6 \pm 7.2^{\dagger}$ & $6.4 \pm 4.9$ \\
Reduction rate & & $34.6 \pm 17.1 \%$ & $51.7 \pm 16.3 \%$ & \\
\hline
\end{tabular}

ADT, androgen deprivation therapy; TUMT, transurethral microwave thermotherapy; TURP Wt, total chip weight of transurethral resection of the prostate; TRUS, transrectal ultrasonography; ${ }^{\dagger}$, one-way ANOVA, repeated measurement, $P=0.0003$.

\section{Histopathologic features of TURP chips}

At least 3 months (mean $3.8 \pm 0.6$ ) after TUMT, continued ADT and administration of PTL for 45 days before and after thermotherapy, TURP was performed in radical fashion. The all TURP chips were subjected to thorough pathologic study in the same manner as the control group by the same single urological pathologist who identified Gleason score of the cancer foci. They revealed remarkable degenerative changes associated with fibrosis in general. In 41 of 45 patients, cancer cell was not detected in TURP chips. In 1 patient, non-viable cancer foci referring to as necrosis and severe 
degenerative changes, cell cytoplasm was homogeneous in appearance and intensely eosinophylic with nuclear piknosis, were found in a small number of TURP chips (Fig. 1). In 3 patients, however, degraded but probably viable cancer cells were detected in TURP chips (Figs. 2-4). Number of patients
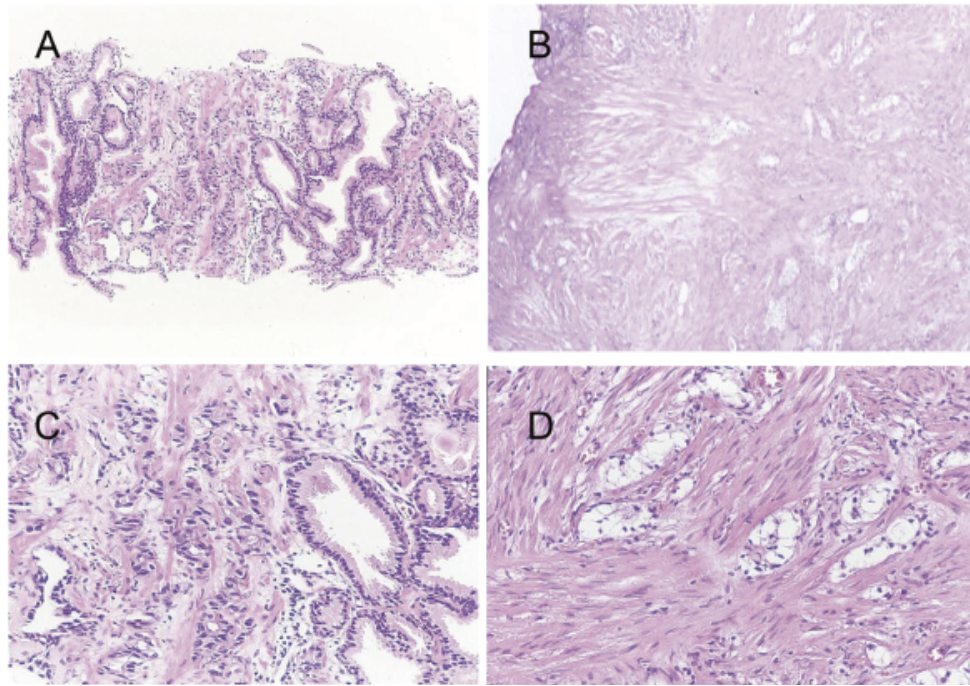

Fig. 1. 73 yrs. PSA $7.8 \mathrm{ng} / \mathrm{ml}$. A, Initial biopsy core from the left mid area: poorly differentiated adenocarcinoma, Gleason score $4+4=8$. Reduced from $\times 100$. B, A typical area of the above. Reduced from $\times 200$. C, Histology of a TURP chip from the apex area, 12 weeks after transurethral microwave thermotherapy pretreated with parthenolide $0.5 \mathrm{mg}$ /daily for 15 days and continued androgen deprivation. Generalized degenerative changes, but with some remnant of probably non-viable cancer cells, in 7 of 20 chips from the apex area. The total number of TURP chips was 73. Reduced from $\times 40$. D, A typical area of the above. Reduced from $\times 200$.

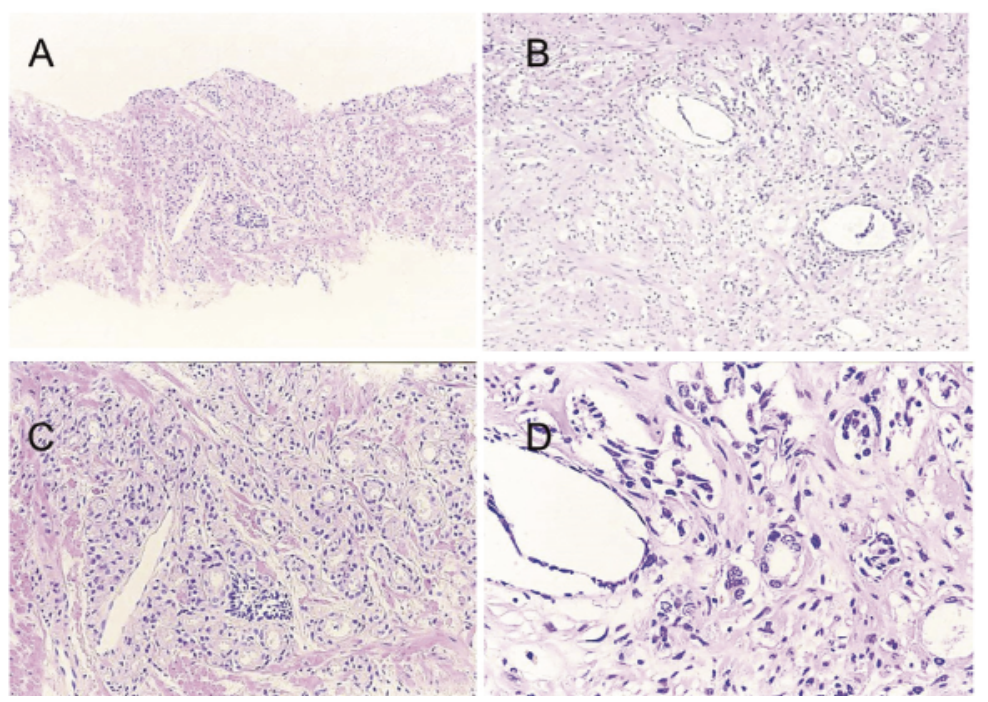

Fig. 2. 71 yrs. PSA $4.8 \mathrm{ng} / \mathrm{ml}$. A, Initial biopsy core from the left apex area; moderately differentiated adenocarcinoma, Gleason score $3+4=7$. Reduced from $\times 100$. B, A typical area of from above. Reduced from $\times 200$. C, Histology of a TURP chip from the left lateral area, 16 weeks after transurethral microwave thermotherapy pretreated with parthenolide $0.5 \mathrm{mg}$ /daily for 15 days and continued androgen deprivation. Generalized degenerative changes, but with some remnant of probably viable but degraded cancer foci in 1 of 14 chips from the left lateral area. The total number of TURP chips was 63 . Reduced from $\times 100$. D, A typical area of the above. Reduced $\times 400$. 

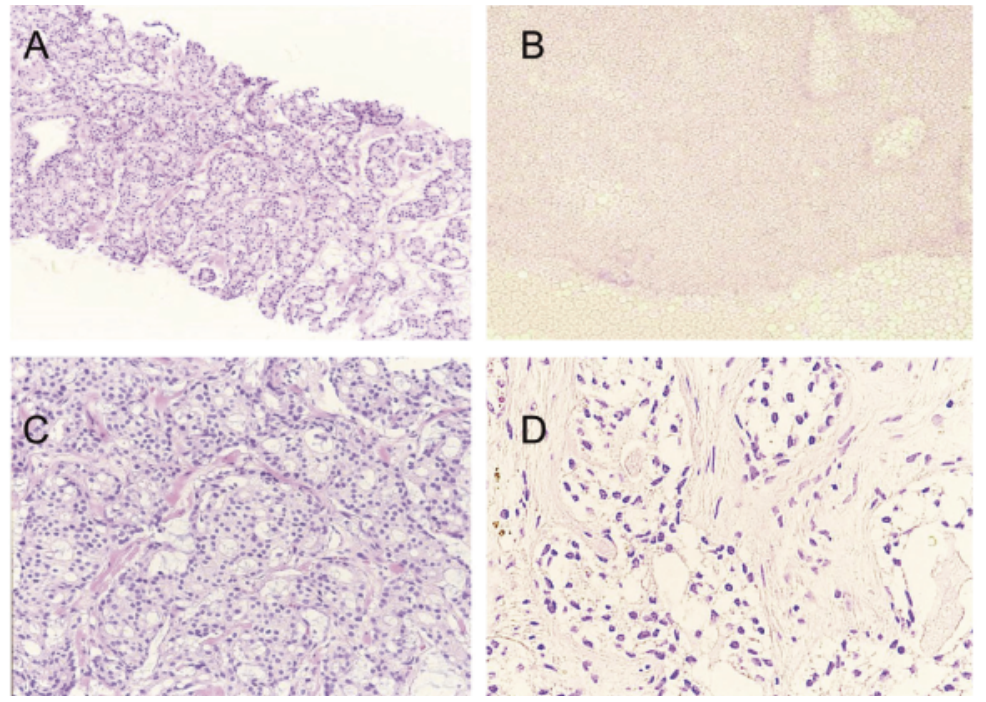

Fig. 3. 67 yrs. PSA $11.8 \mathrm{ng} / \mathrm{ml}$. A, Initial biopsy core from the right apex area ; poorly differentiated mucinous adenocarcinoma, Gleason score $4+4=8$. Reduced from $\times 100$. B, A typical area of the above. Reduced from $\times 200$. C, Histology of a TURP chip from the right lateral area, 16 weeks after transurethral microwave thermotherapy pretreated with parthenolide $0.5 \mathrm{mg}$ / daily for 15 days and continued androgen deprivation. Generalized degenerative changes but with a few remnant of degraded cancer foci, probably of Gleason score $3+4=7$, in 1 chip among 19 chips from the right lateral area. The total number of TURP chips was 70 . Reduced from $\times 40$. D, A typical area of the above. Reduced from $\times 400$.
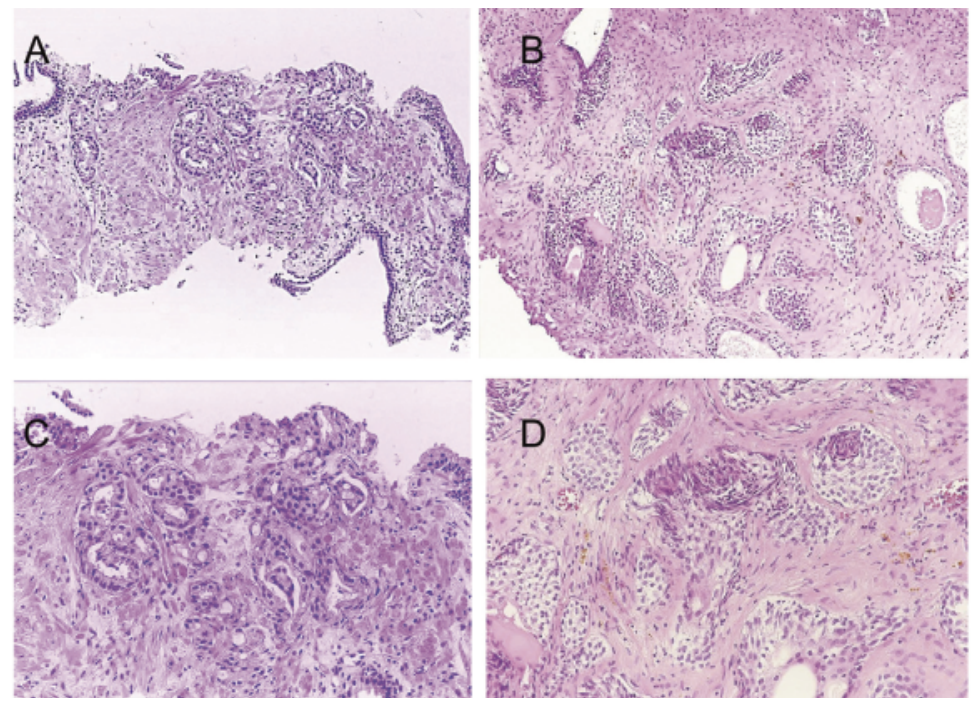

Fig. 4. 79 yrs. PSA $11.3 \mathrm{ng} / \mathrm{ml}$. A, Initial biopsy core from the left base area; moderately differentiated adenocarcinoma, Gleason score $3+4=7$. Reduced from $\times 100$. B, A typical area of the above. Reduced from $\times 200$. C, Histology of a TURP chip from the left lateral area, 18 weeks after transurethral microwave thermotherapy pretreated with parthenolide $0.5 \mathrm{mg}$ / daily for 15 days and continued androgen deprivation. Generalized degenerative changes, but with scattered remnant of probably viable cancer foci, possibly degraded, in about half of TURP chips from the left lateral and apex area. The total number of TURP chips was 158. Reduced from $\times 100$. D, A typical area of the above. Reduced from $\times 200$. 
who had remnant cancer foci in TURP chips was apparently smaller than half of the control group without use of PTL and degenerative change was more remarkable in the PTL group than those of the control group (Table III). The characteristics of the 4 patients with remnant cancer foci in TURP chips are listed in Table IV and those of 16 patients of control group are listed in Table V.

Table III. Historogic difference in TURP chips between patients with parthenolide (PTL) and without PTL.

\begin{tabular}{|c|c|c|c|c|}
\hline & $\begin{array}{l}\text { With PTL } \\
(\mathrm{n}=45)\end{array}$ & $\begin{array}{l}\text { Without PTL } \\
(\mathrm{n}=75)\end{array}$ & $P$-value & $(95 \% \mathrm{CI})$ \\
\hline No remnant cancer & 41 & 59 & 0.061 & Chi-squared \\
\hline Remnant cancer & 4 & 16 & OR 0.36 & $(0.11-1.15)$ \\
\hline \multirow[t]{2}{*}{ (viable, non-viable) } & $(3,1)$ & $(6,10)$ & & \\
\hline & Mean \pm SD (n) & Mean \pm SD (n) & & $t$-test \\
\hline Age (years) & $71.8 \pm 5.6(45)$ & $70.4 \pm 6.3(75)$ & 0.054 & $(-0.09-4.49)$ \\
\hline PSA (ng/ml) & $9.2 \pm 7.8(45)$ & $10.1 \pm 6.7(75)$ & 0.381 & $(-3.84-1.43)$ \\
\hline Prostate volume (ml) & $30.1 \pm 9.9(45)$ & $34.6 \pm 14.2(72)$ & 0.221 & $(-6.62-1.65)$ \\
\hline Gleason score & $\mathrm{n}(\%)$ & n (\%) & & \\
\hline$<6$ & $17(37.8)$ & $41(54.6)$ & 0.189 & Fisher's exact test \\
\hline 7 & $20(44.4)$ & $23(30.7)$ & & \\
\hline$>8$ & $8(17.8)$ & $11(14.7)$ & & \\
\hline
\end{tabular}

Abbreviations as in Table I.

Table IV. Characteristics of 4 patients who had remnant cancer cell in TURP chips (4/45 patients with parthenolide).

\begin{tabular}{|c|c|c|c|c|c|c|c|c|c|c|c|c|}
\hline \multirow[b]{2}{*}{ Patient } & \multirow[b]{2}{*}{$\begin{array}{c}\text { Age } \\
\text { (years) }\end{array}$} & \multicolumn{5}{|c|}{ at Diagnosi } & \multicolumn{4}{|c|}{ sat TURP } & \multicolumn{2}{|c|}{ Pathology } \\
\hline & & $\begin{array}{c}\text { PSA } \\
(\mathrm{ng} / \mathrm{ml})\end{array}$ & $\begin{array}{l}\text { P. vol. } \\
\text { (ml) }\end{array}$ & $\begin{array}{c}\text { Gleason } \\
\text { score }\end{array}$ & Location & Stage & $\begin{array}{l}\text { P. vol. } \\
\text { (ml) }\end{array}$ & $\begin{array}{l}\text { Wt } \\
(\mathrm{g})\end{array}$ & Location & N-chips & $\begin{array}{c}\text { Presumed } \\
\text { Gleason score }\end{array}$ & Viability \\
\hline 1 & 73 & 7.8 & 17.3 & $4+4=8$ & 5,6 & $\mathrm{~T} 2 \mathrm{a}$ & 14.8 & 5.1 & Ap & $7 / 20(73)$ & & non-viable \\
\hline 2 & 71 & 4.8 & 20.7 & $3+4=7$ & $4,5,6$ & $\mathrm{~T} 2 \mathrm{a}$ & 7.8 & 3.6 & LL & $1 / 14(63)$ & - & viable, degraded \\
\hline 3 & 67 & 11.8 & 23.1 & $4+4=8$ & 1 & $\mathrm{~T} 1 \mathrm{c}$ & 14.7 & 5.7 & RL & $1 / 19(70)$ & $3+4=7$ & viable, degraded \\
\hline 4 & 79 & 11.3 & 51.6 & $3+4=7$ & 5,6 & $\mathrm{~T} 2 \mathrm{a}$ & 22.0 & 11.5 & $\begin{array}{l}\text { LL } \\
\text { Ap }\end{array}$ & $\begin{array}{l}32 / 58(158) \\
11 / 34(158)\end{array}$ & $\begin{array}{l}- \\
-\end{array}$ & $\begin{array}{l}\text { viable, degraded } \\
\text { viable, degraded }\end{array}$ \\
\hline
\end{tabular}

P. vol., prostate volume including fibrous capsule measured by ultrasonography; $\mathbf{1}$, right apex ; $\mathbf{4}$, left apex; $\mathbf{5}$, left mid ; 6, left base; Wt, weight of TURP chips; Ap, apex area ; LL, left lateral area; RL, right lateral area; N-chips, number of cancer positive chip/ number of chips in the area (number of total TURP chips)

Table V. Characteristics of 16 patients who had remnant cancer cell in TURP chips (16/75 patients before use of parthenolide).

\begin{tabular}{|c|c|c|c|c|c|c|c|c|c|c|c|c|}
\hline \multirow[b]{2}{*}{ Patient } & \multirow[b]{2}{*}{$\begin{array}{c}\text { Age } \\
\text { (years) }\end{array}$} & \multicolumn{5}{|c|}{ at Diagnosi } & \multicolumn{4}{|c|}{ sat TURP } & \multicolumn{2}{|c|}{ Pathology } \\
\hline & & $\begin{array}{c}\text { PSA } \\
(\mathrm{ng} / \mathrm{ml})\end{array}$ & $\begin{array}{l}\text { P. vol. } \\
(\mathrm{ml})\end{array}$ & $\begin{array}{c}\text { Gleason } \\
\text { score }\end{array}$ & Location & Stage & $\begin{array}{l}\text { P. vol. } \\
\text { (ml) }\end{array}$ & $\begin{array}{l}\mathrm{Wt} \\
(\mathrm{g})\end{array}$ & Location & N-chips & $\begin{array}{c}\text { Presumed } \\
\text { Gleason score }\end{array}$ & Viability \\
\hline 1 & 67 & 8.9 & 28.1 & $2+2=4$ & 4,5 & $\mathrm{~T} 2 \mathrm{a}$ & 12.2 & 7.0 & $\mathrm{Md}$ & $1 / 6(139)$ & $2+3=5$ & viable, degraded \\
\hline 2 & 63 & 6.3 & 33.6 & $\begin{array}{l}2+1=3 \\
3+4=7\end{array}$ & $\begin{array}{l}2 \\
6\end{array}$ & Tlc & 16.0 & 5.0 & $\begin{array}{l}\text { RL } \\
\mathrm{LL}\end{array}$ & $\begin{array}{l}1 / 22(85) \\
4 / 22(85)\end{array}$ & & $\begin{array}{l}\text { non-viable } \\
\text { non-viable }\end{array}$ \\
\hline 3 & 70 & 9.1 & 43.5 & $4+3=7$ & $1,2,3$ & $\mathrm{~T} 2 \mathrm{a}$ & 30.4 & 21.6 & RL & 2/69 (189) & & non-viable \\
\hline 4 & 60 & 20.2 & 18.4 & $\begin{array}{l}3+3=6 \\
4+4=8\end{array}$ & $\begin{array}{l}4 \\
5\end{array}$ & $\mathrm{~T} 2 \mathrm{a}$ & 13.3 & 4.8 & $\begin{array}{l}\text { LL } \\
\text { Ap }\end{array}$ & $\begin{array}{l}1 / 20(69) \\
2 / 14(69)\end{array}$ & & $\begin{array}{l}\text { non-viable } \\
\text { non-viable }\end{array}$ \\
\hline
\end{tabular}


Table V. (continued).

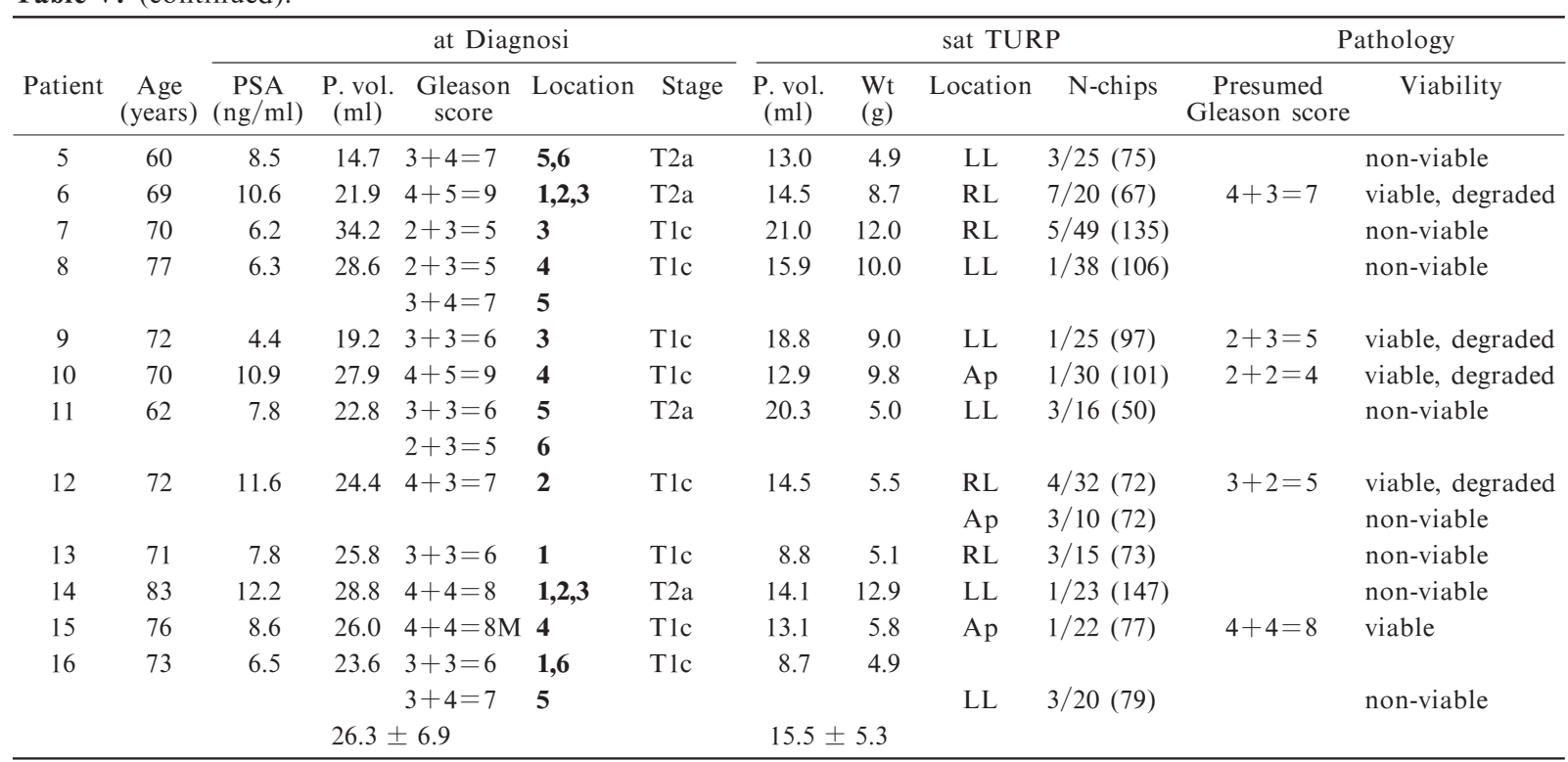

2, right mid; 3, right base; Md, median lobe area; M, mucinous adenocarcinoma; Other abbreviations as in Table IV.

\section{Changes in serum chemistry and PSA levels}

For the initial 30 patients PTL administration was started 30 days before TUMT. Their serum chemistry levels before and after 30days revealed no unfavorable change in any visceral functions and blood components as well. For 15 patients thereafter, PTL administration was started 15 days before TUMT.

Sudden fall in serum PSA was observed after ADT for 3 months. It became almost undetectable after TUMT. After cessation of ADT, 6 months $(6 \times 4$ weeks $)$ after TURP, serum PSA showed gradual elevation, but stayed within normal range $(<4 \mathrm{ng} / \mathrm{ml})$ in majority of the patients. Regarding 8 patients with biopsy Gleason score 8 or greater, one patient showed elevation of serum PSA up to $6.1 \mathrm{ng} / \mathrm{ml}$, at $12^{\text {th }}$ month after cessation of ADT. He has been on intermittent anti-androgen treatment up to date since then, without any clinical evidence of recurrence of the disease. His biopsy Gleason score was 10 and serum PSA was $34.1 \mathrm{ng} / \mathrm{ml}$ at diagnosis (Fig. 5). Although it is still too early to discuss

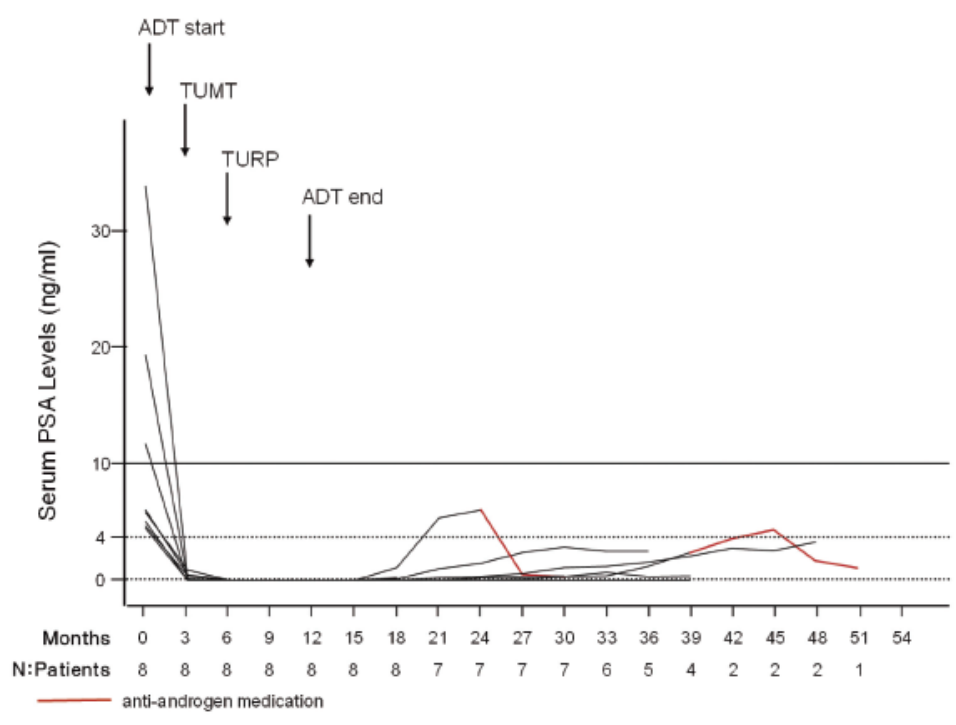

Fig. 5. Changes in serum PSA level during the therapy and follow up period on 8 patients with Gleason score 8 or greater at biopsy diagnosis. One of them has been on anti-androgen therapy (red line). 
on the behavior of serum PSA after this treatment, there has been no statistically meaningful difference between PTL group and control group before administration of PTL.

\section{Complications}

Two patients complained of difficulty in urination due to stricture in posterior urethra. One patient was successfully treated by urethral dilation, however, another patient required internal urethrotomy twice. One patient complained of stress incontinence after TURP, but spontaneously cured by $6^{\text {th }}$ postoperative month. All patients tolerated the scheduled ADT until $6^{\text {th }}$ month after TURP.

\section{Clinical outcome}

The main purpose of this study is to report differences in the irreversible pathologic changes of TURP chips between PTL administered group and control group before the use of PTL. Therefore it is still too early to compare the long term clinical outcome of both groups in the same standard.

One patient developed mild elevation of serum PSA at $12^{\text {th }}$ month and has been on intermittent non-steroidal anti-androgen administration. One patient, 83 years old, died of cardiac accident at home, in 2 months after finishing all the therapeutic procedure, without any relationship with prostate cancer. His last serum PSA was $<0.1 \mathrm{ng} / \mathrm{ml}$ at 2 months before death. The other patients are alive as of February 2013, at a median observation period of 33 months (range 18 51) without any evidence of clinical recurrence of prostate cancer.

\section{Discussion}

The therapeutic effectiveness of heat on malignant tumors has been reported since long ago. There were many reports in the early 1900s on the use of applied hyperthermia in treating cancer in which heat was thought to be the most important factor in causing regression of tumors and even cure ${ }^{15)}$. However, the interest declined in the 1960s possibly due to the decrease of many infectious diseases with the introduction of antibiotics and technical difficulties related to the practical application of hyperthermia.

Localized hyperthermia for prostate cancer using microwave applicator was reported by Mendecki et $a l^{16)}$ though the clinical efficacy remained insufficient mainly because of the transrectal treatment route with the intraprostatic temperature lower than $43^{\circ} \mathrm{C}$. Development of a new system, TUMT ${ }^{17)}$ combines the heating of the prostatic tissue with the conductive cooling of the urethra, accomplished by arranging a chamber around the microwave antenna which is continuously circulated with cooled water. It is also acknowledged that high-energy TUMT is able to destroy prostatic tissue up to a radial distance of $16 \mathrm{~mm}$, while maintaining innocuous urethral and rectal temperature. According to our clinical experiences $^{8)}$, the radial distance from the urethral mucosa to the fibrous capsule of the prostate with the volume of approximately $30 \mathrm{ml}$ is usually within $15 \mathrm{~mm}$, with an $18 \mathrm{~F}$ microwave applicator placed in the urethra. However, one should notice that not all TUMT machines are suitable to treat prostate cancer. Majority of them are designed for the treatment of enlarged lateral lobes of prostatic hyperplasia. It is fortunate for us that the TUMT machine we have used in this study is a very suitable one to treat prostate cancer even in the peripheral zone and/or apex of the prostate by helical coil antenna system ${ }^{8,18)}$.

Though TUMT is capable of heating whole intraprostatic tissue to $45^{\circ} \mathrm{C}$ or higher, it is insufficient 
to deliver therapeutic heat further than $16 \mathrm{~mm}$ from the urethral mucosa. The purpose of $8 \mathrm{MHz}$ radiofrequency capacitive regional hyperthermia is to expect higher treatment effect by additional heating to the fibrous capsule of the prostate and periprostatic region, though the maximum temperature is limited to $43.5^{\circ} \mathrm{C}$. To date, regional hyperthermia is usually performed in combination with another treatment modality, such as radiotherapy or chemotherapy. In this study, we have utilized PTL expecting its thermo-enhancement effect.

The thermo-enhancement effect of the sesquiterpene lactone PTL, which targets the transcription factor $\mathrm{NF}-\varkappa \mathrm{B}$, and hyperthermia at 40,42 and $44^{\circ} \mathrm{C}$ on the human lung adenocarcinoma A549 cell line were investigated and reported by Hayashi et $a l^{6}$ ) in 2008. They hypothesized that cells treated with PTL had an altered arrangement of stressed cells undergoing the transformation from necrotic cell death to apoptotic cell death via another mechanism. Their results suggested that PTL-induced apoptosis of A549 cells was due to the direct suppression of NF- $\varkappa$ B activity in a p53- and hsp72-independent manner based on NF- $\varkappa \mathrm{B}$ signaling. Their subsequent investigation results on the thermo-enhancement effect of PTL on human prostate cancer androgen-independent cell lines ${ }^{7)}$ encouraged us to use PTL in thermotherapy of prostate cancer.

To date, as far as we know, this is the first clinical report to assess the combination therapy of TUMT, regional hyperthermia, ADT and PTL in patients with prostate cancer. We like to conclude that this combination therapy is feasible and administration of PTL may positively contribute to better clinical outcome in patients with early prostate cancer.

\section{References}

1) Wiedhopf R.M., Young M., Bianchi E., Cole J.R. : Tumor inhibitory agent from Magnolia grandiflora (Magnoliaceae) I : Parthenolide. J Pharm Sci, 62: 345, 1973.

2) Hoffman J.J., Torrans S.J., Wiedhoph R.M., Cole J.R. : Cytotoxic agents from Michelia champaca and Talauma ovata : Parthenolide and costunolide. J Pharm Sci, 66: 883-884, 1977.

3) El-Feraly F.S., Chan Y.M.: Isolation and characterization of the sesquiterpene lactons costunolide, parthenolide, costunolide diepoxide, santamarine and reynosin from Magnolia grandiflora L. J Pharm Sci, 67 : 347-350, 1978.

4) Jain N.K., Kulkarni S.K. : Antinociceptive and anti-inflamatory effects of Tanacetum parthenium L. extract in mice and rats. J Ethnopharmacol, 68 : 251-259, 1999.

5) Johnson E.S., Kadam N.P., Hylands P.J. : Efficacy of feverfew as prophylactic treatment of migraine. Br Med J (Clin Res Ed), 291 : 569-573, 1985.

6) Hayashi S., Hatashita M., Hayashi A., Matsumoto H., Shioura H., Kitai R.: Thermosensitization by parthenolide in human lung adenocarcinoma A549 cells and p53- and hsp72-independent apoptosis induction via the nuclear factor- $\varkappa$ B signal pathway. Int J Mol Med, 21: 585-592, 2008.

7) Hayashi S., Koshiba K., Hatashita M., Sato T., Jujo Y., Suzuki R., Tanaka Y., Shioura H. : Thermosensitization and induction of apoptosis or cell-cycle arrest via the MAPK cascade by parthenolide, an NF- $\varkappa \mathrm{B}$ inhibitor, in human prostate cancer androgen-independent cell lines. Int J Mol Med, 28 : 1033-1042, 2011.

8) Koshiba K., Jujo Y., Suzuki R., Ohori M., Aihara M., Nakajo H., Mizoguchi H., Shimura S. : A treatment of localized prostate cancer with high-energy transurethral microwave thermotherapy after reduction of volume of the prostate by androgen deprivation: Eight year experiences. Thermal Med, 27: 69-77, 2011.

9) Epstein J.I., Allsbrook, Jr W.C., Amin M.B., Egevad L.L., ISUP Grading Committee: The 2005 International Society 
of Urological Pathology (ISUP) Consensus Conference on Gleason Grading of Prostatic Carcinoma. Am J Surg Pathol, 29: 1228-1242, 2005.

10) Curry III E.A., Murry D.J., Yoder C., Fife K., Armstrong V., Nakashatri H., O’Connell M., Sweeney C.J. : Phase I dose escalation trial of feverfew with standardized doses of parthenolide in patients with cancer. Invest New Drugs, 22 : 299-305, 2004.

11) Trachtenberg J., Toi A., Yeung E., Habib F.: High temperature microwave thermotherapy of the prostate. Canad J Urol, 1 : 60-65, 1944.

12) Roehrbone C.G., Preminger G., Newhall P., Denstedt J., Razvi H., Chin L.J. : Microwave thermotherapy for benign prostatic hyperplasia with the Dornier UroWave : Results of a randomized, double-blind, multicenter, sham-controlled trial. Urology, 51 : 19-28, 1998.

13) Ohguri T., Imada H., Yahara K., Morioka T., Nakano K., Terashima H., Korogi Y.: Radiotherapy with 8-MHz radiofrequency-capacitive regional hyperthermia for stage III non-small-cell lung cancer: The radiofrequency-output power correlates with the intraesophageal temperature and clinical outcomes. Int J Radiat Oncol Biol Phys, 71 : 128-135, 2009.

14) Ueda K., Maeda F., Ito Y.: Combined treatment with low dose chemotherapy and regional hyperthermia for progressive urothelial cancer. Thermal Med, $27:$ 109-112, 2011.

15) Rohdenburg G.L.: Fluctuations in the growth energy of malignant tumors in man, with especial references to spontaneous regression. J Cancer Res, 3 : 193-225, 1918.

16) Mendecki J., Friedenthal E., Botstein C., Paglione R., Sterzer F. : Microwave applicators for localized hyperthermia treatment of cancer of the prostate. Int J Radiat Oncol Biol Phys, 6: 1583-1588, 1980.

17) Devonec M., Tomera K., Perrin P. : Transurethral microwave heating of the prostate in benign hyperplasia. J Endourol, 7: 255-259, 1993.

18) Nakajo H., Aihara M., Shimura S., Ohori M., Jujo Y., Suzuki R., Koshiba K., Baba S. : The difference in therapeutic effect of transurethral microwave thermotherapy between prostatic cancer and benign prostatic hyperplasia. Kitasato Med J, 36 : 61-67, 2006. 